
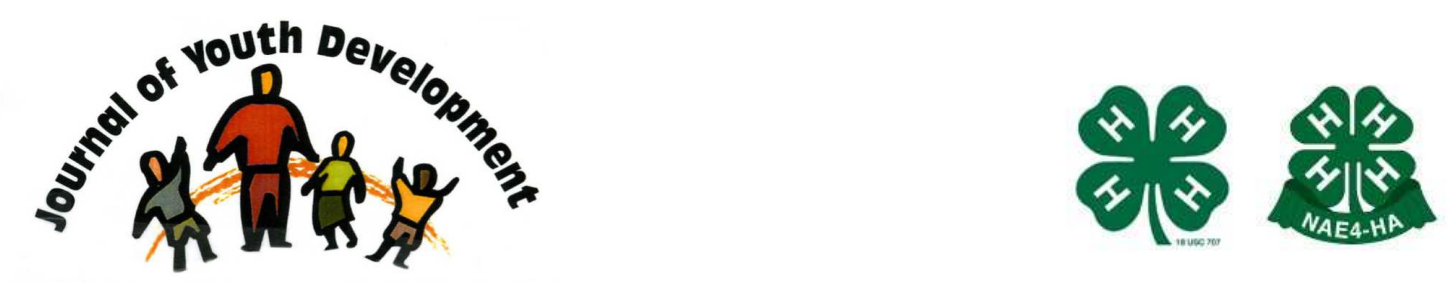

Bridging Research \& Practice

\title{
College 101: \\ Strategies for First Year Success - A Program for High School Seniors
}

\author{
Brian Raison \\ Ohio State University Extension \\ Dayton, Ohio \\ raison.1@osu.edu
}




\title{
JOURNAL OF YOUTH DEVELOPMENT \\ bridging research and practice

\section{College 101: \\ Strategies for First Year Success - A Program for High School Seniors}

Brian Raison

Ohio State University Extension

\begin{abstract}
Making the transition from high school to college can be one of the biggest challenges in life. The first year dropout rate stands at $26 \%$ nationally. Adolescent decision-making literature suggests that youths can achieve greater success and reduce negative consequences during their first year of college if they 1 ) increase knowledge of new social scene and academic protocols, and 2) work through a conjectural decision-making process prior to actual encounters.

This program presents key points high school seniors "must know" in advance of their arrival on campus. It is research-based with first-hand advice from real college students including on-the-street video interviews. Topics cover: Choosing Classes, Test Strategies, Social Scene Changes, Budgeting, Roommates, Safety, Talking with Professors, Time Management, and more. The program is designed for any student planning to attend any 2 or 4-year college. Youth professionals can teach this loosely-scripted 1 or 2-hour PowerPointbased seminar "out of the box." The $\$ 159$ curriculum package is free to the first 250 responders.
\end{abstract}




\section{Background}

Each year, approximately 1.8 million U.S. first-quarter college freshmen encounter the greatest decision-making period of their young lives. Many of their choices will initiate life-long consequences with financial, emotional and physical (health-related) implications. The highest risks include a dramatic loss of earning capacity due to failing or dropping out-26\% freshman non-return rate nationally (ACT, 2004), acquiring a sexually transmitted infection- $25 \%$ of college age youths (CDC, 2004), alcohol poisoning, acquaintance rape, and others.

Conversely, behavioral data on youths show improved decision-making and fewer negative consequences associated with prior encounters or foreknowledge of given life scenarios (Trad, 1993; Wyatt, 1989). Thus, our hypothesis: Youths will achieve greater success and reduce negative consequences during their first year college if they

1) increase knowledge of social scene changes and new academic protocols, and

2) work through a conjectural decision-making process prior to life encounters.

\section{Increased College Prep Efforts}

In recent years, colleges and universities have added "First Year Encounter" seminars aimed at easing social and academic adjustments while lessening dropout potential. Most, however, offer these during the first quarter-too late to provide processing time for risk decision-making. Freshman orientation is offered prior to campus arrival, but tends to focus on class scheduling, placement, library use, and some warnings about crime prevention and underage drinking. In addition, it is predisposed toward a specific institution.

High school guidance counselors work to prepare students for college entry exams, scholarships and financial aid applications. But, they have little time for discussions on social scene changes, campus life, or collegiate academic rigor. The popular press offers several "college survival" titles as antecedents; but reviews are anecdotal and mixed, at best.

The new College 101 curriculum offering stands apart on two key points. First, it is researchbased. Second, it is proffered several months prior to the physical move-the transition-tocollege event. Again, adolescent decision-making theories note the predictive abilities of intervention to influence actual decisions that can forecast outcomes (Mann, Harmoni, \& Power, 1991; Ross, 1981). This previewing technique forms the basic premise of the program.

\section{The Program's Research Basis}

We surveyed over 600 current college students (Ohio State University IRB Protocol \#2006E0643) asking them to provide advice to college-bound high school seniors. Over 280 provided input (Raison, 2006). Key themes were identified and formed the basis of a 2006 pilot college preparatory curriculum. To date, an estimated 3,500 students in 14 states have participated in the seminar. Of 708 collected evaluations, $88.6 \%$ of students said they learned new information and/or that they would recommend the program to a friend.

In late 2006, the University of Wisconsin Research Foundation's Transitions to College Focus Group Study found that many college students wish they had known in high school how much more demanding college would be. They also said that college stress would have been reduced if they had taken more courses to prepare them for college. (Janke, et al, 2006). 
The report recommended "developing workshops for parents and their college-bound students to discuss the social transformations that are coming." They also recommended using current college students "to share their experiences and advice with high school seniors as way to increase their knowledge about academic, social, and financial issues related to the transition to college." The College 101 program directly addresses these recommendations.

The program was built on the framework of Logic Model (University of Wisconsin Extension, 2002). It provided consideration for the context, environment, and input-output factors that described the full chain of events-from inputs to outcomes-and provided accountability at the end of the process. This strengthened the program overall and provided an excellent structure to convey the current collegian advice.

\section{Program Overview}

The College 101 curriculum offers guidance on key issues derived from current collegians that lend stories with peer-to-peer credibility. It approaches high school seniors on their terms utilizing direct quotes from contemporaries to add social scene and classroom stories with "future shock" value. For the 2007 update, we taped "on the street" video interviews with just over 60 college students from three different universities. Now, sixteen edited segments intersperse "live advice" throughout the program.

During the seminar, specific differences between high school and college academic protocols are highlighted. Data on college completion rates are presented as well to show evidence of the difficulty of this endeavor and to invoke a challenge to succeed. Participants receive tips on specific topics such as time management, studying/testing techniques, roommate issues, drug, alcohol, and STD statistics, credit/money management, and more. Questions are posed at given intervals to stimulate discussion and to increase audience participation and engagement.

\section{Program Impact}

Most participants will depart for college within one or two months of completing the program. Move-in day provides the first opportunity to determine program effectiveness. As parents unload cars, unpack boxes and finally depart for home, the complete and total freedom of being away at college will be suddenly realized. If not that very evening, then certainly within the week, first-quarter freshmen will encounter between one and all of the scenarios presented in the program. Their decision-making process will be taxed to the fullest extent. Hopefully, information from the seminar will resonate and help guide their choices.

Making a successful transition is the main goal. The definition of success, particularly within this construct, is expanded to encompass the avoidance of certain behaviors with potentially negative, life-impacting consequences, especially during this first quarter adjustment period. We are now gathering participants' future college email addresses to conduct follow-up surveys during their first quarter of college to determine if and how the program components were recalled, and/or if their decisions were influenced in a positive way. This information will help guide derivative editions of the program.

\section{Teaching the Program}

All materials needed to facilitate this program are on one CD. It can be conducted by: University outreach specialists, 4-H \& Extension Educators, Youth Development Professionals, School 
Counselors, Teachers, Community and Faith-Based Organization Professionals. The CD is formatted to teach the program as a:

1. Stand-alone seminar: The $C D$ includes both 1-hour and 2-hour versions. Audience Size: 10 to 100 (or $200+$ but with less interaction).

2. Classroom series: The $C D$ includes a classroom version with 4-6 lessons of 1-hour each, and additional handouts and discussion points. Audience Size: 5 to 50 optimal.

3. Self-study: This included a new "electronic narrator" as a click-through-guide for student/parent or student/teacher study. Program length is self-determined.

Current collegians may provide highlights and beneficial insight in any teaching application. Educators may wish to preview the program with them; then develop a plan of inclusion with time and topic restrictions. The program CD includes Microsoft's free PowerPoint Viewer. System requirements include Windows 98, XP or newer and most Macintosh operating systems.

\section{Implementing the Program (250 Free)}

The retail price of the curriculum is $\$ 159$ for end-users schools, libraries, or non-profits. An expanded use site-license is available for broad-ranging or state-wide applications. The first 250 Extension Educators (or Journal of Youth Development readers) who respond will receive the program FREE. A $\$ 5 /$ unit shipping and handling fee will be collected. Simply email the author.

Recipients of the free copies will be asked to either teach the seminar or share information about the program with their local high schools. Some schools, guidance counselors and local libraries may want to have their own copies for student self-study and review. They may also want to teach the expanded 4-lesson classroom series (included on the CD) as a special senior session or in a government class. School purchase information is available online at http://college101seminars.com.

For schools with limited or no curriculum budget, the program will be made available to them free of charge. An application is required and a limit may apply.

\section{Cost Recovery}

Some schools have opted to charge a fee for the class, (e.g. \$2-\$5 per senior). This modest expense can help promote buy-in from the participating seniors and can provide a supplement to a curriculum budget year after year.

\section{Expanded Program Use - Admissions Tool}

To date, three universities have expressed interest in customizing the program with their logos, branding, and college-specific information. The program would be sent as a self-study to help prepare admitted students. It would offer a wider array of topics and depth than is afforded during the brief on-campus freshman orientation. It would also provide critical processing time for students prior to their fall campus arrival. A low cost site license for First-Year Experience and Admission Office use is available. 


\section{Conclusions}

Feedback on the research, program content and participant reaction has been overwhelmingly positive. Based on written responses of participants and high interest by school counselors, the program appears to have great potential for impacting the lives of college-bound students. The current college student survey returned more than 1,000 comments citing the need for an intervention program such as this. These excerpts are typical responses:

"I wish I was more confident as a freshman."

"I wasn't prepared to be in control."

"A lot of people aren't ready for college."

The College 101 program combines common threads of readily accessible information into one seminar that is proffered at a critical point in adolescent development. It contributes essential knowledge that will help reduce negative consequences and dropout rates of first-year college freshmen.

\section{Curriculum Highlights}

The curriculum has undergone numerous blind peer reviews among colleagues in universities across the country. It has received several honors and invitations noted below.

\section{Awards:}

1st Place: National Association of Extension 4-H Agents (NAE4HA) - National Winner of the 2007 Educational Program Package Prize. Presentation: October 25, 2007, Atlanta, Georgia.

\section{Invited Presentations:}

- Children, Youth \& Families at Risk (CYFAR) Annual Conference. Chicago, Illinois - May 1-4, 2007. (Program workshop on methodology / peer inclusion using College 101 model.)

- National Association of Community Development Extension Professionals (NACDEP) Annual Conference. Philadelphia, Pennsylvania - April 16-19, 2007. (Complete curriculum.)

- Building Human \& Social Capital: The Knowledge Economy Conference - Ohio State University. Columbus, Ohio - May 2, 2006. (White paper.)

- National Association of Extension 4-H Agents (NAE4HA) Conference. Seattle, Washington October 30 - November 3, 2005. (Pilot curriculum.)

\section{Reviews / Comments:}

"The transition from high school to college can be the most difficult transition in life. But it doesn't have to be. College 101 gives students exactly what they need: a realistic picture of what's ahead, combined with practical tools to navigate the challenges. "- Derek Melleby, College Transition Specialist, Center for Parent/Youth Understanding (http://www.cpyu.org)

"The difficulty of making the transition from high school senior to college freshman is well documented. Along with the first year dropout rate, students face enormous social and academic pressures. Built on a sound research base, the College 101 program provides excellent advice gathered directly from the front line: current college students. The video segments bring great credibility in a peer-to-peer learning model that really connects with 
college-bound students." - Theresa Ferrari, Ph.D., Associate Professor and Extension Specialist, The Ohio State University.

"It is yet another great tool for school counselors to use as they help students successfully plan for their futures. "- Kelley S. Schubert, MS, LPSC, President, Ohio School Counselor Association

\section{References}

ACT (2004). National Dropout and Degree Completion Tables. Retrieved April 7, 2006 from http://www.act.org

Centers for Disease Control and Prevention (2005). Summary of notifiable diseases, United States, 2004. National Center for HIV, STD, and TB Prevention, Division of STD Prevention. Sexually transmitted disease surveillance, 2004. US Department of Health and Human Services. Atlanta, GA. Retrieved December 2006, from http://www.cdc.gov

Janke, J., Speerstra, M., Trechter, D. (2006). Transitions to College Focus Group Report DRAFT. Madison, Wisconsin: University of Wisconsin Research Foundation.

Mann, L., Harmoni, R., \& Power, C. (1991). Teaching decision making to adolescents. In Baron, J., \& Brown, R. V. (eds.) The GOFER course in decision making, pp. 61-78. Hillsdale, NJ: Lawrence Erlbaum Associates.

Raison, B. (2006). Current College Student Advice Survey Results (PRELIMINARY). College of Food, Agriculture and Environmental Science, Department of Extension, The Ohio State University.

Ross, J. A. (1981). Improving adolescent decision-making skills. Curriculum Inquiry, 11, 279295.

Trad, P. V. (1993). The ability of adolescents to predict future outcome. Part1: Assessing predictive abilities. Adolescence, 28, 533-555.

University of Wisconsin-Extension (2002). The Logic Model. Program Development \& Evaluation http://www.uwex.edu/ces/pdande/

Wyatt, G. (1989). Decision-making under conditions of risk: Assessing influential factors. The Emporia State Research Studies. Emporia, KS: Emporia State University. 


\section{Suggested Reading}

A Shared Agenda: A Leadership Challenge to Improve College Access and Success. (2004). Retrieved December 26, 2006, from the Pathways to College Network, http://www.pathwaystocollege.net

Barefoot, B. (2000). The First-Year Experience-Are We Making It Any Better? About Campus, 4(6), 12-18. Retrieved Friday, April 07, 2006 from the ERIC database.

College Survival Tips, Academics, Transition Tips. (2006). Retrieved June 2004 and September 2005 from http://www.collegeboard.com/student/plan/college-success/

Cushman, K. (2005). First in the Family: Advice about college from first-generation students. Providence, Rhode Island: Next Generation Press.

Donham J. (2003). My Senior Is Your First-Year Student: High School Transition to College. Knowledge Quest [serial online]. 32(1):32-32. Available from: ERIC, Ipswich, MA. Accessed April 7, 2006.

Kidwell, K., \& Reising, B. (2005). Understanding the College First-year Experience. Clearing House, 78(6), 253-255. Retrieved Friday, April 07, 2006 from the Academic Search Alumni Edition database.

Khullar, M. (2006) 9 College Myths (and why they're just not true). Next Step Mag, March/April 2006, pp20-21. Victor, NY

Lotkowsik, V., Robbins, S., Noeth, R., (2004). The Role of Academic and Non-Academic Factors in Improving College Retention. ACT Policy Report. Retrieved December 11, 2004 from http://www.act.org/research/policy/index.html

Melleby, D., (2006) College Transition Initiative. The Center for Parent/Youth Understanding. Retrieved October 2006 from http://cpyu.org/

National Research Council Institute of Medicine (1999). Adolescent decision making: Implications for prevention programs. Retrieved November 20, 2004, from the U.S. Dept. of Health \& Human Services web site http://www.aspe.hhs.gov/hsp/adolescent99/issues.htm

Ohio State University (2004). First Year Experience: Success Series. OSU FYE. Columbus, Ohio. Retrieved June 2004 from the Ohio State University web site: http://fye.osu.edu/success.html and from https://admissions.osu.edu/fye/fye.asp

Rainey, D. and B., \& Burns, B. (2004). Protecting Your Kids In College. Family Life Today radio series, Little Rock, AR, March 17-19, 2004. Retrieved June 2004 from web site:

http://www.familylife.com

Sax, L. J. (2004). The American Freshman: National Norms for Fall 2003. Retrieved September 12, 2004 from the UCLA, Higher Education Research Institute, Graduate School of Education and Information Studies web site: http://www.gseis.ucla.edu/heri/03 press release.pdf 
Summary of Results from the 2003 National Survey on First-Year Seminars. (2004). Retrieved September 26, 2004 from the University of South Carolina, National Resource Center for the First Year Experience and Students in Transition web site:

http://www.sc.edu/fye/research/surveyfindings/surveys/survey03.html

Thompson, B., Thornton, H. (Summer 2002). "The Transition from extrinsic to intrinsic motivation in the college classroom: A first-year experience," Education, vol 122 no 4, pp. 785792.

UCLA (2007). Degree Attainment Rates at American Colleges \& Universities. Retrieved 20042007 from UCLA, Higher Education Research Institute, Graduate School of Education web: http://www.gseis.ucla.edu/heri

Zlotkowski, Edward, Ed. (2002). Service-Learning and the First-Year Experience: Preparing Students for Personal Success and Civic Responsibility. The First-Year Experience Monograph Series. National Resource Center for The First-Year Experience and Students in Transition. Columbia, SC: University of South Carolina.

(C) Copyright of Journal of Youth Development $\sim$ Bridging Research and Practice. Content may not be copied or emailed to multiple sites or posted to a listserv without copyright holder's express written permission. However, users may print, download or email articles for individual use. 